\title{
Incidence and Ecology of Blackberry yellow vein associated virus
}

James Susaimuthu and Rose C. Gergerich, Department of Plant Pathology, and Mark M. Bray, Kimberley A. Clay, and John R. Clark, Department of Horticulture, University of Arkansas, Fayetteville 72701; Ioannis E. Tzanetakis, Department of Botany and Plant Pathology, Oregon State University, Corvallis 97331; and Robert R. Martin, Horticultural Crops Research Lab, United States Department of Agriculture-Agricultural Research Service, Corvallis, OR 97330

\begin{abstract}
Susaimuthu, J., Gergerich, R. C., Bray, M. M., Clay, K. A., Clark, J. R., Tzanetakis, I. E., and Martin, R. R. 2007. Incidence and ecology of Blackberry yellow vein associated virus. Plant Dis. 91:809-813.

Symptoms of leaf vein yellowing and bush decline in blackberry were attributed to infection by a novel crinivirus named Blackberry yellow vein associated virus (BYVaV). The disease is an emerging threat to blackberry production because it can cause substantial yield loss. The objective of this study was to identify the source and means of spread of BYVaV. A survey of blackberry plants for BYVaV from wild, cultivated, and nursery stocks was conducted. Insect traps and healthy blackberry sentinel plants were placed among symptomatic plants in a production field throughout two growing seasons to monitor the occurrence of potential vectors and virus spread. Virus indicator plants were grafted with BYVaV-infected blackberry because this virus was latent in some blackberry cultivars, but indicator plants failed to express symptoms when infected with BYVaV. Reverse-transcription polymerase chain reaction detection revealed the occurrence of BYVaV in blackberry nurseries in the United States, in production fields in Arkansas, South Carolina, and North Carolina, and in wild blackberry populations in Arkansas. Whiteflies (Trialeurodes packardii and T. ruborum), potential vectors of BYVaV, were observed on sticky traps placed in blackberry fields and were found colonizing blackberry plants; however, transmission studies failed to produce whitefly-mediated transmission of BYVaV. Further understanding of the disease etiology is needed to devise viable management strategies for this disease.
\end{abstract}

Additional keywords: blackberry yellow vein disease, Rubus

Blackberry (Rubus subgenus Rubus L.), a choice crop for small-fruit growers in the United States, was harvested from more than 3,900 ha and valued at $\$ 37$ million in 2005 (2). The fruit is valuable because of its nutritional qualities and consumer preference. Blackberry fruit is processed into jam, jelly, syrup, and other value-added products besides being an excellent fruit for fresh market. Nearly $75 \%$ of blackberry production in the United States occurs in Oregon, and most of the blackberry crop produced in this state is processed. In recent years, demand for fresh fruit has led to increased cultivation of blackberry in the southern United States. The growing popularity of blackberry as a crop has been associated with the release of improved cultivars suitable for the fresh fruit market (3). Further, blackberry acreage is pre-

Corresponding author: R. C. Gergerich

E-mail: gergeric@uark.edu

Accepted for publication 14 January 2007.

doi:10.1094/PDIS-91-7-0809

This article is in the public domain and not copyrightable. It may be freely reprinted with customary crediting of the source. The American Phytopathological Society, 2007. dicted to expand by $8 \%$ of the present area by the year 2008 , primarily in the southern United States (10).

Acreage devoted to blackberry production in the United State is threatened by blackberry yellow vein disease (BYVD). Blackberry yellow vein associated virus (BYVaV), a newly described crinivirus, has been identified as a consistent component of the disease $(8,12)$. The symptoms include progressive leaf vein yellowing (Fig. 1), poor fruit flavor, die-back of floricanes, and bush decline. Vein yellowing occurs on floricanes and primocanes, with young leaves on primocanes appearing symptomless. A preliminary electron microscopic examination of sap from symptomatic leaf tissue revealed flexuous rodshaped virus particles (11). Subsequent extraction of double-stranded RNA (dsRNA) and analysis through cloning and sequencing identified a new virus designated as BYVaV, a member of the genus Crinivirus (12). BYVaV was found to be a consistent component of the disease $(8,12)$.

Members of the genus Crinivirus are regarded as emerging viruses that cause new plant diseases worldwide. Vector transmission of these pathogens has been demonstrated in a semipersistent manner by whiteflies, the natural vectors of crini- viruses $(17,18)$. Expanded ranges of whiteflies and agricultural trade practices involving movement of plant materials have contributed to the spread of criniviruses.

Symptomatic blackberry plants from several locations in the United States previously have tested positive for $\mathrm{BYVaV}$ $(8,12)$. Although BYVaV is consistently associated with BYVD, it appears to be latent in several blackberry cultivars (12). A thorough understanding of the prevalence, mode of transmission, and involvement of $\mathrm{BYVaV}$ in symptom expression is required to manage BYVD. The objectives of this study were to assess the occurrence of BYVaV in cultivated, wild, and nursery blackberry plants; to understand the means of transmission of BYVaV; and to identify indicator plants suitable for BYVaV indexing.

\section{MATERIALS AND METHODS}

RNA extraction and reversetranscription polymerase chain reaction. For detection of BYVaV, a reversetranscription polymerase chain reaction (RT-PCR) assay was performed using leaf $(100 \mathrm{mg}$ ) or petal tissue (about 10 petals). Total RNA was extracted following a modified protocol by Hughes and Galau $(7,12)$. An RT-PCR reaction was performed in a two-step procedure. First, a $10-\mu l$ cDNA synthesis reaction mixture containing $1 \mu \mathrm{l}$ of the RNA extract, $0.5 \mu \mathrm{l}$ of random primers $(0.5 \mu \mathrm{g} / \mu \mathrm{l}), 2 \mu \mathrm{l}$ of $5 x$ RT buffer, $0.5 \mu \mathrm{l}$ of $10 \mathrm{mM}$ dNTPs, $1 \mu \mathrm{l}$ of $100 \mathrm{mM}$ dithiothreitol, and $0.25 \mu \mathrm{l}$ of MMLV reverse transcriptase (Promega Corp., Madison, WI) was incubated at $42^{\circ} \mathrm{C}$ for 50 min followed by a denaturation step at $80^{\circ} \mathrm{C}$ for $10 \mathrm{~min}$. In the second step, primers designed to amplify a portion of the BYVaV polymerase region (Table 1) were used to amplify a segment of the virus genome for detection purposes. In addition, portions of BYVaV RNA1 and RNA2 (Table 1) also were amplified and sequenced to determine nucleotide sequence similarities among symptomatic field plants, asymptomatic nursery plants, and wild blackberry plants infected with $\mathrm{BYVaV}$ from three locations. The following components were used in a $25-\mu \mathrm{l}$ PCR reaction for template amplification: $2.5 \mu \mathrm{l}$ of $10 \times$ thermophilic DNA polymerase buffer, $2.0 \mu \mathrm{l}$ of $25 \mathrm{mM} \mathrm{MgCl} 2,0.5 \mu \mathrm{l}$ of $10 \mathrm{mM}$ dNTPs, $10 \mathrm{pmol}$ of each primer, 18 
$\mu \mathrm{l}$ of sterile water, $1.0 \mu \mathrm{l}$ of the cDNA template, and $0.2 \mu \mathrm{l}$ ( 1 unit) of Taq polymerase (Promega Corp.). The thermocycler (DNA Engine PTC-0200; MJ Research, Inc., Waltham, MA) was programmed for a 5min denaturation at $94^{\circ} \mathrm{C}$; followed by 40 cycles of $30 \mathrm{~s}$ at $94^{\circ} \mathrm{C}, 30 \mathrm{~s}$ at $55^{\circ} \mathrm{C}$, and $60 \mathrm{~s}$ at $72^{\circ} \mathrm{C}$; with a final extension step of $10 \mathrm{~min}$ at $72^{\circ} \mathrm{C}$. Amplified products were cloned in pCR4.0 vector using the TOPO Cloning Kit (Invitrogen, Carlsbad, CA). Sequencing was performed at the University of Arkansas Molecular Core Laboratory. Sequences were compared with the published BYVaV sequences in the National Center for Biotechnology Information database using the BLAST program (1).

Nucleic acid spot hybridization. Total RNA was extracted from virus-infected and healthy blackberry plants as described above. A series of RNA concentrations from 100 to $6.1 \mathrm{ng} / \mu \mathrm{l}$ was prepared by making twofold dilutions of the RNA extract in a final volume of $10 \mu \mathrm{l}$ to identify the threshold level for detection of BYVaV. The samples were heat denatured at $70^{\circ} \mathrm{C}$ for $10 \mathrm{~min}$ and blotted on a positively charged nylon membrane (Roche Applied Science, Indianapolis, IN) using a dot-blot

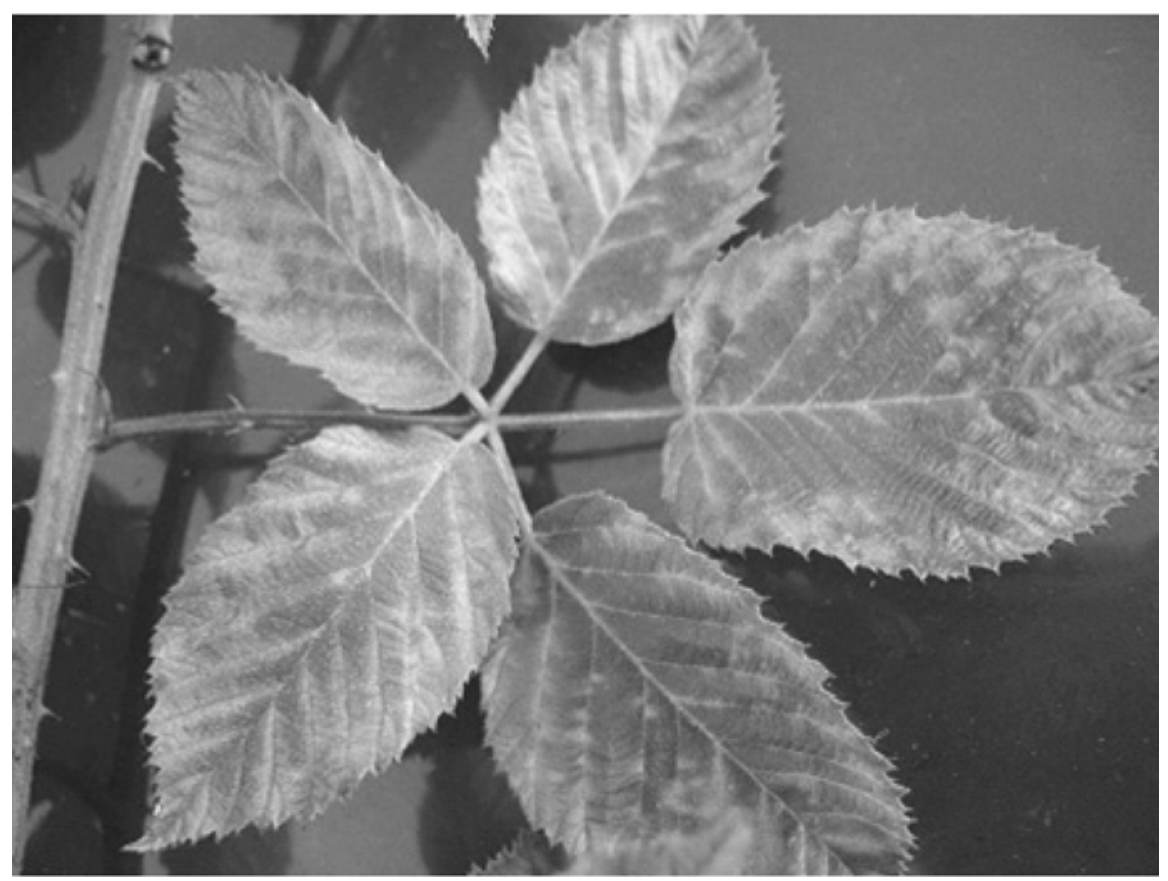

Fig. 1. Symptoms of yellow vein disease in Chickasaw blackberry infected with Blackberry yellow vein associated virus.

Table 1. Primers used in reverse-transcription polymerase chain reaction detection and sequencing of Blackberry yellow vein associated virus (BYVaV)

\begin{tabular}{lllc}
\hline Primer name & \multicolumn{1}{c}{ Primer sequence $\left(\mathbf{5}^{\prime}-\mathbf{3}^{\prime}\right)$} & \multicolumn{1}{c}{ Target } & $\begin{array}{c}\text { GenBank } \\
\text { accession no. }\end{array}$ \\
\hline BYVaV PF & GGGTTAATGAGAGATTGGATG & $\ldots$ & AY548174 \\
BYVaV PR & TGGGATTTGTCAAACTTGGTG & Polymerase region & $\ldots$ \\
BYVaV1F & TGAAACCGTCACTCAAGCTG & $\ldots$ & AY776334 \\
BYVaV1R & TGACACCAAAAGGGAAGGTC & BYVaV RNA1 & $\ldots$ \\
BYVaV2F & TGTTTATGCGATCGGTGTGT & $\ldots$ & AY776335 \\
BYVaV2R & ACTTGGCATAATCGGAAACG & BYVaV RNA2 & $\ldots$ \\
\hline
\end{tabular}

included in the survey were Apache, Chickasaw, Triple Crown, and Chester. The participating nurseries represented five regions of the United States, including midsouth, southeast, midwest, northeast, and the Pacific Northwest. Test materials were obtained either as whole plants, root cuttings, or both. The plants and root cuttings were grown in a greenhouse in which an insecticide spray program was used to control whiteflies, aphids, and mites. Fully matured, pooled leaves from two plants of each cultivar from one location constituted a sample for RT-PCR analysis for the presence of BYVaV.

Survey of wild blackberry. Leaf samples were collected in Arkansas from floricanes of wild blackberry plants in May 2004, and the sites were marked with a global positioning system. In May 2005, petal samples were collected in a similar manner from floricanes for detection of $\mathrm{BYVaV}$ from the same geographic areas as in 2004. Leaf and petal samples were stored on ice soon after collection and subsequently were frozen at $-20^{\circ} \mathrm{C}$ until extraction. RT-PCR as described above was used for detection of the virus in the leaf and petal samples.

Blackberry production fields. Blackberry leaf samples and root cuttings of symptomatic plants were sent by growers in Arkansas, Georgia, Tennessee, Kentucky, South Carolina, and North Carolina. Plants were propagated from the root cuttings, and tests were performed on submitted leaf samples and on leaves derived from plants grown from the root cuttings.

Sentinel plants and sticky traps. In summer 2004 and 2005, a study was conducted to determine if and when BYVaV was spreading from infected Chickasaw blackberry plants to healthy blackberry sentinel plants in a northwest Arkansas production field. A set of 10 healthy tissue culture-propagated Chester blackberry plants (actively growing and 20 to $35 \mathrm{~cm}$ in height) was placed in the field in the upper canopy of symptomatic blackberry plants for each 2-week period spanning the blackberry-growing season (April to October). Each test plant was accompanied with a yellow sticky trap (10 by $16 \mathrm{~cm}$ ) placed in the vicinity, and potential vectors such as whiteflies were identified by examining the flag under a dissecting microscope. The insect traps were prepared by using wires to form a support frame for the yellow plastic sheet which was dipped in melted Tangle-Trap (Tangle-Trap; The Tanglefoot Company, Grand Rapids, MI). Each year, 10 plants were maintained in the greenhouse to serve as healthy controls. All sentinel and control plants were maintained in the greenhouse following removal from the field, and the plants were overwintered outdoors in a cold frame covered with bark mulch. The plants were returned to the greenhouse in March, and fully mature leaves were analyzed 4 weeks 
later by RT-PCR for BYVaV as described above. A pesticide spray program involving Isotox (Ortho, Marysville, $\mathrm{OH}$ ) and Kelthane (Dow AgroSciences, Indianapolis, IN) was followed routinely to keep the greenhouse free of insects and mites throughout the study period.

Vector transmission. Whiteflies are vectors of criniviruses (18). To test for BYVaV transmission, whiteflies were collected with the use of an aspirator from young leaves in the upper canopy of symptomatic blackberry plants in the production field in northwest Arkansas. Approximately 25 whiteflies per plant were delivered immediately to five healthy blackberry plants each of cvs. Arapaho, Black Diamond, Chester, Marion, and Ouachita and five plants each of Cucumis sativus L. cv. Boston Pickling and Nicotiana benthamiana L. Two species of whiteflies, Trialeurodes packardii, the strawberry whitefly (identified by Dr. Judith Brown, University of Arizona), and T. ruborum Cockerell, the Rubus whitefly (identified by Gregory A. Evans, Systematic Entomology Laboratory, Agriculture Research Service, United States Department of Agriculture, Beltsville, MD), were observed naturally inhabiting blackberry plants in the field. Both whitefly species were used in a mixture for transmission of $\mathrm{BYVaV}$ because the adult insects were morphologically indistinguishable from one another. In addition to direct transmission attempts, whiteflies obtained from the field were raised on BYVaV-free Chester blackberry plants in the greenhouse. Whiteflies from the colony then were allowed to feed on a BYVaV-infected Chickasaw plant for

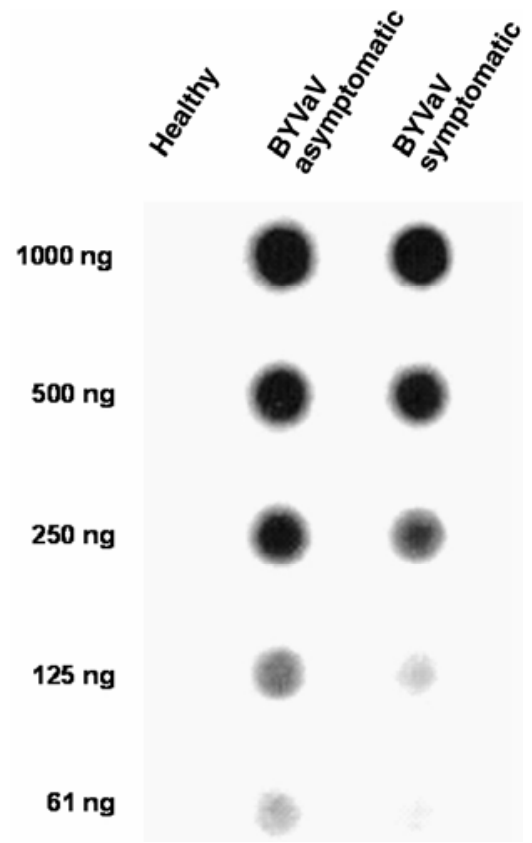

Fig. 2. Nucleic acid spot hybridization detection of Blackberry yellow vein associated virus (BYVaV) in Chickasaw blackberry using a BYVaV-specific probe. a 24-h acquisition-access period. Subsequently, 40 insects per plant were transferred to three healthy blackberry plants each of Marion, Chester, and Chickasaw and three $N$. benthamiana plants to feed for a 24-h inoculation-access period, after which the plants were sprayed with Isotox (Ortho). N. benthamiana plants were observed for 4 weeks for signs of virus symptoms. Blackberry test plants were monitored for 1 year for symptom expression and then tested by RT-PCR for evidence of BYVaV infection.

Seed transmission. Blackberry plants are not propagated through seed commercially, but seed transmission is an important consideration in breeding programs. Although there is no evidence for seed transmission of criniviruses in the literature, we performed this assay to determine whether seed transmission of BYVaV should be a concern for breeders. In July 2004, fruit from BYVaV-infected Chickasaw plants in the field were collected and cleaned, and the resulting seeds were dried and treated to break dormancy as follows. The dried seeds were completely immersed in concentrated sulfuric acid, and the acid-seed mixture was stirred occasionally for $3 \mathrm{~h}$ in a beaker placed in an ice bath. The treated seeds were collected in a strainer and washed with running water for 5 min. The strainer with seeds was immersed twice in a solution containing sodium bicarbonate $(60 \mathrm{~g}$ per $500 \mathrm{ml})$ for 30 $s$ and rinsed with running water after each immersion. The treated seeds were mixed with moist potting soil and stratified for 5 months at $4{ }^{\circ} \mathrm{C}$ to promote germination. The seeds were sown in plastic trays ( 70 by 40 by $10 \mathrm{~cm}$ ) filled with potting mixture in the greenhouse in January 2005, and 200 individual seedlings were tested for BYVaV after 2 months by RT-PCR.

Indicator plants. Virus indexing of blackberry is done by grafting leaves or canes of mother plants of commercial cultivars onto virus-sensitive indicator plants to test for latent virus infections (4). Scions of BYVaV-infected asymptomatic Chickasaw blackberry plants obtained from a blackberry nursery were bottle grafted (5) to Munger black raspberry (the most commonly used Rubus virus indicator), Marion blackberry, and Meeker red raspberry for evaluation as indicators for BYVaV. The indicator plants were obtained from the National Clonal Germplasm Repository, Corvallis, OR, and three plants per cultivar were used.

\section{RESULTS}

Virus detection. In our study, RT-PCR was used routinely as a method of choice for BYVaV detection. Nucleic acid spot hybridization (NASH) was developed as an alternative to RT-PCR in the latter part of the study because inhibition of RT-PCR sometimes was observed while testing mature blackberry leaves. Both RT-PCR and NASH were used successfully to detect BYVaV. RT-PCR with BYVaVspecific primers (BYVaV PF and BYVaV PR; Table 1) yielded the expected 500-bp amplicon (data not shown). RNA dot-blot hybridization experiments offered reliable detection of the virus for all RNA concentrations tested (Fig. 2).

Survey for BYVaV. The nationwide survey of blackberry nursery stocks identified the presence of $\mathrm{BYVaV}$ in all five regions studied (Table 2), even though none of the plants that tested positive for BYVaV infection was symptomatic. BYVaV was detected frequently from the midsouth region, where all three of the blackberry cultivars tested from two locations contained the virus. Although sampling was on a smaller scale, BYVaV was detected from one cultivar from one location each in the other four regions tested.

In 2004, we identified BYVaV in wild blackberry leaves from 1 location in northwest Arkansas out of the 52 locations sampled throughout the state. All wild blackberry plants sampled were asymptomatic. In 2005, testing of petal samples

Table 2. Regions and cultivars of blackberry plants sampled in the nationwide survey of licensed blackberry-propagating nurseries for the presence of Blackberry yellow vein associated virus (BYVaV)

\begin{tabular}{lllll}
\hline & \multicolumn{4}{c}{ Blackberry cultivar ${ }^{\mathrm{a}}$} \\
\cline { 2 - 5 } Region & Apache & Chickasaw & Triple Crown & Chester \\
\hline
\end{tabular}

\begin{tabular}{|c|c|c|c|c|}
\hline \multicolumn{5}{|l|}{ Midsouth } \\
\hline Nursery 1 & - & - & $*$ & * \\
\hline Nursery 2 & + & + & + & $*$ \\
\hline Nursery 3 & + & + & + & $*$ \\
\hline Nursery 4 & - & - & - & - \\
\hline \multicolumn{5}{|l|}{ Southeast } \\
\hline Nursery 1 & - & - & $*$ & * \\
\hline Nursery 2 & - & - & - & - \\
\hline Nursery 3 & $*$ & + & - & * \\
\hline \multicolumn{5}{|l|}{ Midwest } \\
\hline Nursery 1 & - & $*$ & - & - \\
\hline Nursery 2 & - & $*$ & + & - \\
\hline Northeast & $*$ & $*$ & + & - \\
\hline Pacific Northwest & $*$ & + & - & - \\
\hline
\end{tabular}

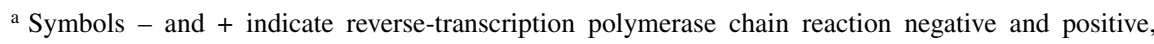
respectively, for BYVaV; * indicates no samples obtained. 
collected from wild blackberry plants from similar, but not identical, geographic areas as in 2004 revealed latent infection of BY$\mathrm{VaV}$ in plants from 6 of 50 locations tested (Fig. 3).

Of the six BYVD samples sent in by blackberry growers from midsouth and southeast production regions, only three tested positive for BYVaV (Arkansas and North and South Carolina). Samples received from Georgia, Tennessee, and Kentucky tested negative for BYVaV.

RT-PCR amplification products from the $\mathrm{BYVaV}$ polymerase region of eight infected samples (nursery stock-2, wild blackberry-2, and production fields-4) were cloned and sequenced. Analysis by BLAST (1) revealed that the sequences were identical $(>99 \%)$ to each other and to part of the BYVaV genomic sequence derived from a cultivated blackberry (GenBank accession no. AY548174). Additional amplifications involving segments of BYVaV RNA1 and RNA2 from asymptomatic Chickasaw nursery stock and symptomatic cultivated plants showed high sequence similarity (>99\%), whereas the BYVaV sequences from wild blackberry plants (GenBank accession nos. DQ901374, DQ910491, and DQ910492) exhibited slightly lower similarity (approximately 93\%) compared with the BYVaV sequences in Chickasaw.

Virus transmission. No visible symptoms were observed in any of the 240 Chester sentinel plants that were placed in the field in 2004 and 2005. All RT-PCR tests on leaf tissue from sentinel plants following a period of vernalization were negative for BYVaV.

All life stages of whiteflies were found on blackberry leaves, and high numbers of adult whiteflies (T. packardii and T. ruborum) occurred in the symptomatic production field in northwest Arkansas. The adult whitefly population peaked in July and August, as determined by counts on sticky traps. However, whitefly transmission experiments with both species of the insects did not result in the transfer of $\mathrm{BYVaV}$ to any of the healthy blackberry or herbaceous indicator plants. The lack of whitefly transmission of BYVaV to test plants agrees with the finding that BYVaV was not transmitted to sentinel plants in the field. In the seed-transmission assay for BYVaV, the 200 seedlings did not exhibit symptoms or test positive for the virus in RT-PCR tests.

Viable grafts of asymptomatic BYVaVinfected Chickasaw plants were established on Marion blackberry, Meeker red raspberry, and Munger black raspberry. None of these potential indicators showed visible symptoms of virus infection even though, subsequent to grafting, all the virus source and test plants tested positive for BYVaV in RT-PCR tests.

\section{DISCUSSION}

A recently described virus, $\mathrm{BYVaV}$, is closely associated with vein-yellowing and decline symptoms in blackberry in the United States. Survey of blackberry nurseries (Table 2), detection in production fields, and extensive sampling of wild

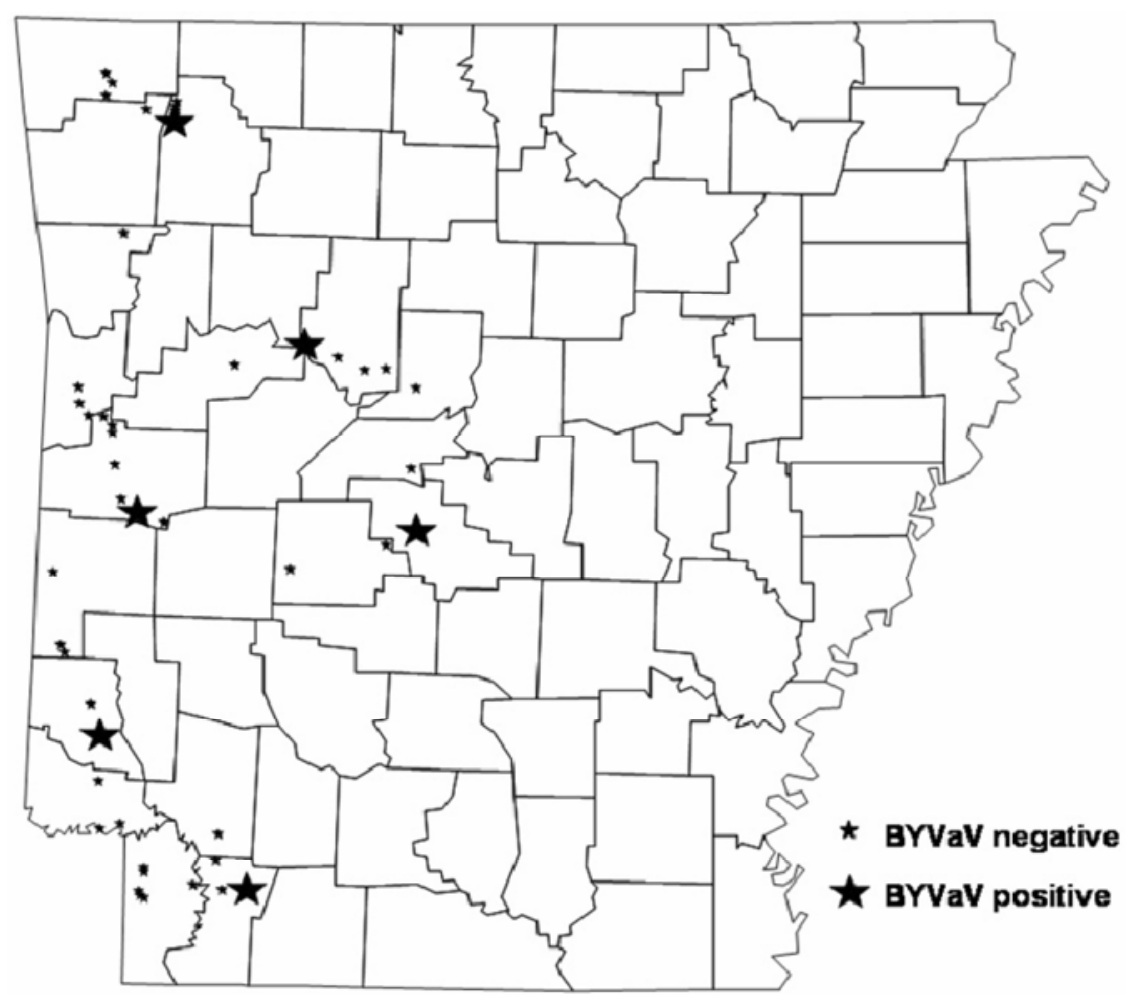

Fig. 3. Map locations of wild blackberry plants sampled in Arkansas for the presence of Blackberry yellow vein associated virus (BYVaV). blackberry plants in Arkansas (Fig. 3) revealed widespread occurrence of this new virus. Although most symptomatic plants showing BYVD symptoms tested positive for $\mathrm{BYVaV}$, there also were 15 asymptomatic plants of three cultivars from blackberry nurseries and wild blackberry plants that were found to be infected with BYVaV. Some of these plants were maintained in the greenhouse for up to 3 years and no obvious symptoms of virus infection were observed during this time. One possibility for appearance of symptoms in some of the plants infected with $\mathrm{BYVaV}$ is that the nucleotide sequence of the virus from symptomatic plants is different enough from that of viruses in asymptomatic plants to allow for variable symptom expression. The RT-PCRamplified BYVaV polymerase regions from symptomatic and asymptomatic blackberry samples were identical. Furthermore, a 566-bp region of RNA1 and a 549-bp region of RNA2 of BYVaV sequences from two each of the symptomatic and asymptomatic plants were found to be identical, which confirms an earlier report that suggested that $\mathrm{BYVaV}$ is latent in some of the blackberry cultivars (12), and that the expression or lack of symptom expression in BYVaV-infected plants probably is not due to the occurrence of BYVaV variants.

The lack of vector transmission in our study may be due to several reasons. Viruses in clonally propagated plants may gradually lose their vector transmissibility if vector transmission is no longer critical for finding new hosts (13). Recently, it was shown that Abutilon mosaic virus, a vector-nontransmissible geminivirus that historically infects plants by graft inoculation, becomes whitefly transmissible after replacement of three amino acids in the coat protein gene (6). Blackberry is propagated primarily through root cuttings, and BY$\mathrm{VaV}$ was found to be widespread in clonally propagated nursery stock. The lack of diversity between BYVaV isolates from asymptomatic blackberry nursery plants and symptomatic field plants compared with lower sequence similarities with BYVaV from infected wild blackberry plants (approximately 93\%) suggests the possibility that BYVaV has long been established in native blackberry plants in Arkansas, and the transmission to cultivated blackberry was a relatively recent and likely single or very rare event. Based on nucleotide sequence analysis, BYVaV is closely related to Beet pseudo-yellows virus and Strawberry pallidosis associated virus, two criniviruses that are transmitted by the greenhouse whitefly ( $T$. vaporariorum) (16). It is possible that an unknown species of whitefly or another aerial vector may be involved in transmitting BYVaV in the field. Attempts to raise greenhouse whiteflies on blackberry plants were unsuccessful; as a result, the greenhouse 
whitefly was not used in transmission studies. Alternatively, BYVaV may be transmitted by one or both of the two species of whiteflies found on cultivated blackberry plants in the field, but with very low transmission efficiency. Criniviruses are not known to be seed transmitted, which is consistent with the results of our blackberry seedling tests; therefore, the occurrence of $\mathrm{BYVaV}$ in wild populations of blackberry plants suggests the possibility of vector transmission. It is possible that BYVaV isolates in wild blackberry plants, which are only $93 \%$ similar to isolates from cultivated blackberry plants, are transmitted by whiteflies. The transmission studies reported here were done with whiteflies collected from BYVaV-infected commercial Chickasaw blackberry plants. Further studies using BYVaV isolates from wild blackberry, which probably are being transmitted in nature, are needed to determine whether these isolates of BYVaV are whitefly transmitted.

The failure of grafted Rubus plants, including the common virus indicator Munger, to express symptoms and the latent infection of commercial cultivars suggests that BYVaV may have been long established in blackberry populations in the United States but escaped detection until recently. There is a need to find BY$\mathrm{VaV}$ indicator plants for use by blackberry nurseries as an inexpensive detection method for this virus in their stock plants. Detection of BYVaV by RT-PCR and NASH in symptomatic field plants and symptomless wild blackberry and nursery plants demonstrates the usefulness of these techniques for detecting latent infections. It should be noted that RNA extracted from petals resulted in more consistent amplification of the virus (J. Susaimuthu, personal observation), which may be due to reduced inhibitor levels compared with leaf extracts. These methods can be utilized to screen for $\mathrm{BYVaV}$ in valuable blackberry nursery stock. Detection by NASH is preferable because this method can be used to assay large numbers of samples simultaneously. In addition, NASH also offers sensitive detection of BYVaV from RNA extracted from mature blackberry leaves that may contain inhibitors of the RT-PCR reactions.

The failure to detect BYVaV in three of the symptomatic blackberry plants in this study could be explained by the presence of inhibitors in the RT-PCR reactions, though repeated tests on these samples makes this unlikely. Another possibility is that these plants could have been infected with Beet pseudo yellows virus (BPYV), which has been reported in blackberry (15). In strawberry, BPYV causes symptoms similar to those caused by Strawberry pallidosis associated virus (14), and it is possible that a similar scenario occurs in blackberry.

Whiteflies have been regarded as emerging pests globally and particularly in North America for the last 10 years (17). The increase in whitefly populations and their spread into new geographic regions has been proposed to explain the appearance of Tomato chlorosis virus and Tomato infectious chlorosis virus, two new criniviruses infecting tomato (Lycopersicon esculentum Mill.) in North America since the 1990s $(19,20)$. We speculate that the occurrence of BYVaV in wild blackberry plants in Arkansas may have been influenced by the involvement of an aerial vector such as whiteflies.

Though BYVaV does not appear to produce symptoms on its own in many blackberry cultivars, mixed infections with additional viruses may be the cause of leafyellowing symptoms. Establishing blackberry stock free of this virus will be a valuable step toward managing this disease. Identification of BYVaV-resistant blackberry plants through screening of a diverse collection of blackberry germplasm or utilization of transgenic mediated resistance are other approaches to develop new cultivars to ensure protection from this virus in the expanding blackberry industry of the United States.

\section{ACKNOWLEDGMENTS}

This project was funded by the Arkansas State Plant Board, the North American Bramble Growers Association, the Arkansas Agricultural Experiment Station, and the United States Department of Agriculture. We thank S. Drake (blackberry grower in Arkansas) for allowing us to use his planting for this study, and also nursery owners and growers who have sent us samples.

\section{LITERATURE CITED}

1. Altschul, S. F., Madden, T. L., Schäffer, A. A., Zhang, J. Zhang, Z., Miller, W., and Lipman, D. J. 1997. Gapped BLAST and PSI-BLAST: a new generation of protein database search programs. Nucleic Acids Res. 25:3389-3402.

2. Anonymous. 2005. Noncitrus fruits and nuts. USDA. Economics, Statistics and Market Information System. Published online.

3. Clark, J. R. 1999. University of Arkansas fruit varieties: sources of blackberries, grapes, and blueberries. Univ. Ark. Coop. Ext. Serv. MP 418.

4. Converse, R. H. 1987. Virus diseases of small fruits. U.S. Dep. Agric. Res. Serv. Agric. Handb. 631.
5. Garner, R. J. 1979. The Grafter's Handbook. Oxford University Press, New York.

6. Höhnle, M., Höfer, P., Bedford, I. D., Briddon, R. W., Markham, P. G., and Frischmuth, T. 2001. Exchange of three amino acids in the coat protein results in efficient whitefly transmission of a nontransmissible Abutilon mosaic virus isolate. Virology 290:164-171.

7. Hughes, D. W., and Galau, G. 1988. Preparation of RNA from cotton leaves and pollen. Plant Mol. Biol. Rep. 6:253-257.

8. Martin, R. R., Tzanetakis, I. E., Gergerich, R. C., Fernandez, G., and Pesic, Z. 2004. Blackberry yellow vein associated virus: A new crinivirus found in blackberry. Acta Hortic. 656:137-142.

9. Sambrook, J., Fritsch, E. F., and Maniatis, T. 1989. Molecular Cloning: A Laboratory Manual, 2nd ed. Cold Spring Harbor Laboratory Press, Cold Spring Harbor, NY.

10. Spiers, J. M., Pittman, P. O., and Braswell, J. H. 1998. An Overview of the Leading Small Fruit Crops Grown in the United States. World Conference on Horticultural Research, Rome.

11. Susaimuthu, J., Tzanetakis, I. E., Gergerich, R. C., and Martin, R. R. 2005. Evidence for mixed infections by two or more viruses causing severe symptoms and decline of blackberry. (Abstr.) Phytopathology 95:S101.

12. Susaimuthu, J., Tzanetakis, I. E., Gergerich, R. C., and Martin, R. R. 2006. Yellow veinaffected blackberries and the presence of a novel Crinivirus. Plant Pathol. 55:607-613.

13. Tomaru, M., Maruyama, W., Kikuchi, A., Yan, J., Zhu, Y., Suzuki, N., Isogai, M., Oguma, Y., Kimura, I., and Omura, T. 1997. The loss of outer capsid protein $\mathrm{p} 2$ results in nontransmissibility by the insect vector of rice dwarf phytoreovirus. J. Virol. 71:8019-8023.

14. Tzanetakis, I. E., and Martin, R. R. 2004. Complete nucleotide sequence of a strawberry isolate of Beet pseudo yellows virus. Virus Genes 28:239-246.

15. Tzanetakis, I. E., and Martin, R. R. 2004. First report of Beet pseudo yellows virus in blackberry in the United States. Plant Dis. 88:223.

16. Tzanetakis, I. E., Wintermantel, W. M., Cortez, A. A., Barnes, J. E., Barrett, S. M., Bolda, M. P., and Martin, R. R. 2006. Epidemiology of Strawberry pallidosis-associated virus and occurrence of pallidosis disease in North America. Plant Dis. 90:1343-1346.

17. Wintermantel, W. M. 2004. Emergence of greenhouse whitefly (Trialeurodes vaporariorum) transmitted criniviruses as threats to vegetable and fruit production in North America. APSnet feature article. Online publication.

18. Wisler, G. C., Duffus, J. E., Liu, H. Y., and Li, R. H. 1998. Ecology and epidemiology of whitefly-transmitted closteroviruses. Plant Dis. 82:270-279.

19. Wisler, G. C., Li, R. H., Liu, H.-Y., Lowry, D., and Duffus, J. E. 1998. Tomato chlorosis virus: A new whitefly-transmitted, phloem-limited bipartite closterovirus of tomato. Phytopathology 88:402-409.

20. Wisler, G. C., Liu, H. J. -Y., Klaassen, V. A., Duffus, J. E., and Falk, B. W. 1996. Tomato infectious chlorosis virus has a bipartite genome and induces phloem-limited inclusions characteristic of the closteroviruses. Phytopathology 86:622-626. 